\title{
The influence of relatedness and organizational resources on teaching motivation in continuing higher education
}

\author{
Uwe Wilkesmann (D) $\cdot$ Ronja Vorberg
}

Received: 7 June 2021 / Revised: 19 August 2021 / Accepted: 13 September 2021 / Published online: 6 October 2021

(C) The Author(s) 2021

\begin{abstract}
This article will answer the research question if relatedness and organizational resources influence the teaching motivation in continuing higher education, whereby a distinction is made between intrinsic and extrinsic motivation. Self-determination theory is used as the theoretical underpinning. We conducted a survey of 549 continuing higher education university faculty. Regression analysis determined that relatedness was correlated with intrinsic teaching motivation but was not correlated with extrinsic teaching motivation. Meanwhile, organizational resources increase both intrinsic and extrinsic teaching motivation. Professors are more extrinsically motivated than other faculty. The older university faculty tends to be less extrinsically and more intrinsically motivated. Additionally, female university faculty are more intrinsically motivated than male university faculty.
\end{abstract}

Keywords Teaching motivation $\cdot$ Relatedness $\cdot$ Continuing higher education in Germany

Uwe Wilkesmann $(\triangle) \cdot$ Ronja Vorberg TU Dortmund University, Dortmund, Germany

E-Mail: Uwe.wilkesmann@tu-dortmund.de

Ronja Vorberg

E-Mail: Ronja.vorberg@tu-dortmund.de 


\section{Der Einfluss von sozialer Einbettung und organisationalen Ressourcen auf die Lehrmotivation in der wissenschaftlichen Weiterbildung}

Zusammenfassung Der Artikel beantwortet die Forschungsfrage, ob soziale Einbettung und organisationale Ressourcen die Lehrmotivation in der wissenschaftlichen Weiterbildung beeinflussen. Als theoretischer Hintergrund dient die Self-Determination-Theory. Die Frage wird mit Hilfe eines Datensatzes von 549 befragten Lehrenden in der wissenschaftlichen Weiterbildung beantwortet. Die Regressionsanalyse zeigt, dass die soziale Einbettung Einfluss auf die intrinsische, nicht aber auf die extrinsische Lehrmotivation hat. Gleichzeitig erhöhen angemessene organisationale Ressourcen sowohl die intrinsische als auch die extrinsische Lehrmotivation. Professorinnen und Professoren sind eher extrinsisch motiviert als andere Lehrkräfte. Die älteren Lehrenden sind tendenziell weniger extrinsisch und eher intrinsisch motiviert. Darüber hinaus sind weibliche Lehrende intrinsischer motiviert als männliche Kollegen.

Schlüsselwörter Lehrmotivation · Soziale Einbettung · Wissenschaftliche Weiterbildung in Deutschland

\section{Introduction}

Teaching in continuing higher education in the German Higher Education System (HES) is an exceptional situation because it is optional for university faculty. The required teaching load that each member of a university faculty has, relates entirely to teaching in the traditional undergraduate and graduate programs, and does not relate to the teaching in continuing higher education. What then motivates university faculty who do in fact teach in continuing higher education? Furthermore, if researchers want to make a career in academia, then mainly their achievements in research will count-teaching in continuing higher education is not necessary for a career at a research university. The teaching-learning context in continuing higher education is a special case. Students in continuing higher education are adults who study parallel to their job, have professional experience, and are responsible for financing their studies themselves. Consequently, the teaching faculty have to deal with the special demands that these students bring with them. This requires the university faculty to reflect on their previous teaching activities and, if necessary, adapt them to the new heterogeneous target group (De Vito 2009). Taken together, this leads us to ask why anyone would teach in continuing higher education.

There are almost no studies of teaching motivation in continuing higher education, but there are a few reviews of faculty participation in online distance education (Maguire 2005). If teaching motivation has been investigated, then it has been conducted in the traditional undergraduate studies and has not examined the question of continuing higher education (Daumiller et al. 2020; Wilkesmann and Lauer 2020) or the motivation of students in continuing higher education (Völkening et al. 2010; Johnson et al. 2016). The reasons why university faculty become involved in continuing higher education are often related to the joy they feel in dealing with adult 
students. The intention to transfer their knowledge into practice is also frequently mentioned (Wilkesmann et al. 2020a). To illustrate the teaching motivation of continuing higher education faculty, this article uses Self-Determination Theory (SDT) as a theoretical underpinning. SDT has frequently been used in recent years to investigate the relationship between motivation and organization (Ryan and Deci 2000, 2013, 2020; Donald et al. 2019; Hagger and Hamilton 2020; Tang et al. 2020; Wilkesmann and Schmid 2014). One important aspect within SDT is the influence of relatedness and organizational resources, which has not until now been specifically focused on in terms of the question of the transferability of SDT to teaching motivation in continuing higher education. SDT addresses the influence of social norms as relatedness to others and the organizational environment on motivation. Organizational resources can come across as situative conditions with a supportive character. As a result, individuals are able to evolve and modify their abilities. Examples are conditions regarding work activities, operational conditions and other means, which enable individuals to cope with work related requirements and to master or at least tolerate different challenges (Drzymala 2005). Examples of continuing higher education in Germany are additional staff that supports all organizational and management aspects according to organize the teaching. In Germany, this often includes providing food and beverages to students in the classroom during the continuing higher education seminar to create a pleasant learning atmosphere. Academics will be motivated to teach in continuing higher education if they feel that they can relate to the social norms of an organization that values teaching in continuing higher education and if they feel supported with appropriate resources by the university. Therefore, this article will address the following research question:

Do perceived relatedness and organizational resources influence teaching motivation in continuing higher education?

Since teaching in Germany is additionally paid for in the continuing higher education and empirical evidence exists showing that professors are highly intrinsically motivated in undergraduate and graduate teaching (Wilkesmann and Schmid 2012; Wilkesmann and Lauer 2020), we focus on extrinsic and intrinsic teaching motivation. We show what influences intrinsic and extrinsic teaching motivation and thus when university faculty are motivated to undertake teaching in continuing higher education. To understand the question of teaching motivation in continuing higher education in Germany, this article will first explain the context of the German HES, in which continuing higher education plays a special role. The main aspects of SDT will then be described. Thereby we focus on extrinsic and intrinsic teaching motivation. This is followed by a discussion of the previous findings of the connection between teaching motivation in continuing higher education and SDT. The methodology will describe the survey, where we used an adaptation for continuing higher education of the SDT teaching motivation questionnaire (Wilkesmann and Schmid 2012). It will also describe the survey method and the characterization of the respondent sample. This also allows us to give at least an approximate overview of who in Germany is involved in teaching in continuing higher education. Finally, the empirical part will include two regression models that test the hypotheses. This is followed by a presentation and discussion of the results. The final section of this paper will draw the conclusions, for instance that university faculty are especially 
intrinsically motivated to teach in continuing higher education when they perceive high relatedness. The final section will also describe the limitations, and will make some recommendations for further work.

\section{Continuing higher education in Germany}

HES in Germany can be divided into two parts. In the first part, the required teaching load of the university faculty is concentrated on traditional undergraduate and graduate courses. Teaching is by contract obligatory in the traditional undergraduate and graduate courses for university faculty, while the students do not have to pay tuition fees for traditional undergraduate and graduate courses. Therefore, this part is supply-oriented and the universities develop study programs that students can attend if they want to (Hüther and Krücken 2018). For-profit universities have only a very minor role in the German HES (Lenhardt et al. 2012). In the second part, teaching in continuing higher education is optional for university faculty-no one can force them to teach these courses. Students in continuing higher education return to university in a later stage of the student-life cycle. If they have worked in their profession for a while and then want to attend continuing higher education at a university while working, then these students have to pay high tuition fees. In this article, we define adult students as already having a university degree and work experience, and who then return to university for continuing higher education (Khiat 2017; Woods and Frogge 2017; for definitions of non-traditional student see Schütze and Slowey 2002). In the literature, continuing higher education is partly subsumed under the label "Third Mission" (Berghaeuser and Hoelscher 2020, p. 57). By law, continuing higher education must be charged at least with cost-covering fees and should even generate a profit. Therefore, this part of the German HES is market driven and demand-oriented (Franz and Feld 2015; Wilkesmann 2010). In contrast to traditional undergraduate and graduate teaching at public universities, continuing higher education has to be financed by tuition fees paid by the students. Consequently, the teaching-learning situation is twofold different from that of traditional undergraduate and graduate teaching (Mörth 2020). First, students become customers who also bring along previous knowledge from their work experience, which means that they have corresponding demands. In addition, these students show a high degree of heterogeneity with regard to their professional, educational and life biographies, as well as their study interests and expectations (Mörth 2020). Second, this experience is connected with a strong cultural break in the German HES given that students are not used to paying a lot of money for their studies. If the students have to pay money in this situation, then they could become picky and demanding. This also changes the relationship between students and university faculty. In continuing higher education, adult students return to university with a lot of practical knowledge from their professions. Consequently, they not only look for scientific reflection knowledge for their practice but much more than undergraduate students they also want to contribute their own knowledge to the teaching. Mintzberg (2004) described this as "experienced reflection" in the case of a Master's of Business Administration (MBA): "the managers bring their experience to the classroom, 
where the faculty introduce various concepts, theories, models. We can say that managers live in the territory while the faculty provide the maps" (Mintzberg 2004, p. 264). The relationship between university faculty and students is more an egalitarian exchange relationship than for undergraduate students. Consequently, previous knowledge must be integrated into the program and practical relevance must be constantly established to ensure that the newly acquired knowledge can also be used by the participants in the professional context. Meanwhile, university faculty must deal with these expectations and react accordingly (Wilkesmann et al. 2020a). Khiat (2017) gives empirical evidence that adult students have a lot of competencies in self-directed learning. This is the reason why instructional design plays an important role in continuing higher education (Lim et al. 2019). These challenges make the question of what actually motivates university faculty to teach in this area even more relevant.

There is also a segmentation of the HES in German-speaking countries in terms of the difference between universities of applied sciences and research universities (Wilkesmann 2013; Hüther and Krücken 2018). Universities of applied sciences differ fundamentally from research universities in three aspects (Wilkesmann 2013):

1. Universities of applied sciences are teaching universities. The professors can only use a small part of their working time for research and their teaching load is twice as high as at research universities. While professors at universities of applied sciences must teach $18 \mathrm{~h}$ per week, professors at research universities only have to teach $9 \mathrm{~h}$ per week.

2. The career path to professorship is different—professors at a university of applied sciences must have a doctorate and have worked for at least five years, not less than three from which must have been outside the university (i.e., in industry). Thus, all professors at universities of applied science have practical experience and still have close contacts to companies and/or their former employers. Consequently, they are very much closer to the problems of entrepreneurial practice and they are more likely to take up viewpoints from practice in continuing higher education. In contrast, in addition to their doctorate, professors at research universities must have an academic qualification for a professorship consisting of a 'habilitation' (German professorship examination) or a successfully evaluated junior professorship. Therefore, most professors at research universities have followed a purely academic career.

3. Professors at research universities have research assistants (often many). Professorships are mostly organized as chairs. At universities of applied sciences, professors work usually without assistants.

The first two criteria suggest that professors at universities of applied sciences have a closer relationship to continuing higher education in terms of content because theory and practice are connected in this field (Cendon 2019). However, they already have a high teaching load and therefore are probably less interested in giving additional continuing higher education courses.

Taking on a teaching position in continuing higher education does not have a positive effect on academic reputation for university faculty nor do they receive any special recognition for their work. The contractually agreed tasks of academic em- 
ployees and professors include research, and traditional undergraduate and graduate teaching, but they do not include teaching in continuing higher education. Teaching in continuing higher education is entirely optional for professors and it is usually paid extra because it is additional to the normal teaching load.

The activities of the HES are arranged hierarchically—at research universities research comes first, followed by undergraduate and graduate teaching, while teaching at continuing higher education comes last (Wilkesmann et al. 2020b). Even professors at universities of applied sciences also want to be perceived as researchers. Consequently, it is important to ask what motivates professors and other university faculty to become involved in continuing higher education. Do the aspects that motivate include additional payments or joy to teach interesting people from whom the university faculty can also learn something? And, which organizational resources can support this teaching? In this paper, we will try to answer these questions with the help of SDT.

\section{Self-determination theory and teaching motivation in continuing higher education}

\subsection{Self-determination theory}

SDT (Ryan and Deci 2000, 2013, 2020) is characterized by two main assumptions. First, it is assumed that there is a connection between the perceived organizational situation in which an individual finds themself and a type of motivation or regulation. Second, it is assumed that the organizational situation either enables a feeling of selfdetermination, or creates a feeling of being determined by others or by structures. These different perceptions in turn give rise to different forms of motivation. Thus, motivation also depends on the resources that the organization makes available to the employee. Without any support by resources, the employees feel overwhelmed and as a consequence are amotivated (Ryan and Deci 2013).

Finally, derived from its basic assumptions, SDT constructs a continuum extending from heteronomy to self-determination, depending on the perception of the organizational situation that individuals find themself in (see Fig. 1). The different forms of motivation within this continuum reflect the extent to which a (required) behavior has been internalized and integrated by the individual (Ryan and Deci 2000). When individuals internalize and assimilate regulations, they experience greater autonomy in action (Ryan and Deci 2000).

For Ryan and Deci (2000), intrinsic motivation is located at one end of the continuum (see Fig. 1), is associated with a high degree of self-determination, and is defined as an internally regulated type of action. In intrinsic motivation, behavior is performed because the activity itself is interesting or involves pleasure (Ryan and Deci 2013). Amotivation is on the opposite side of the continuum (see Fig. 1). When they feel amotivated, individuals perceive the situation as overburdened because they do not have the resources that they need to successfully achieve their goals. The individual either does not act at all or only fakes action (Ryan and Deci 2000). In addition, the individual does not feel competent and does not expect a desired 


\begin{tabular}{|c|c|c|c|c|c|}
\hline \multicolumn{6}{|c|}{ Perception of Environment } \\
\hline $\begin{array}{c}\text { Non-Self- } \\
\text { Determined }\end{array}$ & & & & & Self-Determinec \\
\hline Amotivation & & Extrin & tivation & & Intrinsic \\
\hline $\begin{array}{c}\text { Non- } \\
\text { Regulation }\end{array}$ & $\begin{array}{c}\text { External } \\
\text { Regulation }\end{array}$ & $\begin{array}{l}\text { Introjected } \\
\text { Regulation }\end{array}$ & $\begin{array}{l}\text { Identified } \\
\text { Regulation }\end{array}$ & $\begin{array}{l}\text { Integrated } \\
\text { Regulation }\end{array}$ & $\begin{array}{l}\text { Intrinsic } \\
\text { Regulation }\end{array}$ \\
\hline $\begin{array}{l}\text { Perception of } \\
\text { Incompetence, } \\
\text { Lack of Control }\end{array}$ & $\begin{array}{c}\text { External } \\
\text { Rewards and } \\
\text { Punishments }\end{array}$ & $\begin{array}{c}\text { Internal } \\
\text { Rewards and } \\
\text { Punishments }\end{array}$ & $\begin{array}{c}\text { Personal } \\
\text { importance, } \\
\text { Conscious } \\
\text { Valuing }\end{array}$ & $\begin{array}{l}\text { Synthesis with } \\
\text { Self, } \\
\text { Congruence }\end{array}$ & $\begin{array}{l}\text { Enjoyment, } \\
\text { Inherent } \\
\text { Satisfaction }\end{array}$ \\
\hline
\end{tabular}

Degree of Internalization

Fig. 1 Self-determination theory. (Own illustration based on Ryan and Deci 2000, p. 72)

outcome from their own actions. Individuals who are amotivated do not feel that there is a link between their actions and their consequences (Tang et al. 2020). There are different forms of extrinsic motivation on the scale between intrinsic motivation and amotivation (see Fig. 1). These are basically characterized by the fact that individuals want to achieve a result with their performance that can be separated from the action itself (Ryan and Deci 2000). The four qualitatively different forms of extrinsic motivation vary in the extent to which regulation is perceived as controlled or autonomous (Ryan and Deci 2000, 2013). External regulation is a form of extrinsic motivation that corresponds to a still high degree of heteronomy (see Fig. 1), which refers to behaviors that are undertaken to obtain a reward or avoid punishment (Ryan and Deci 2013). In the case of teaching in continuing higher education, this is the opportunity to earn additional money. Introjected motivation is a relatively controlled form of regulation where an individual performs an action due to internal pressure, such as guilt, preventing fear, or improving their ego (Tang et al. 2020; Ryan and Deci 2000). Here is an example that the teaching is well prepared, because otherwise there will be a guilty conscience. Identified motivation is a more autonomous or selfdetermined form of extrinsic motivation (see Fig. 1). Identification refers to social norms of the peer-group (Ryan and Deci 2000). If a professor belongs to a peergroup of other professors where teaching in continuing higher education is very highly respected, then the motivation may be based in compliance with this norm. Integrated motivation occurs when identified regulations are fully assimilated into the self, which means that they have been evaluated and are in accordance with one's own needs (Ryan and Deci 2000). For example, a professor has a self-image of herself or himself as the perfect teacher in continuing higher education.

SDT assumes that extrinsically motivated actions can also become self-determined, provided that individuals identify with them and completely assimilate their regulation (Ryan and Deci 2000). This process of internalization does not take place in such a way that individuals move through each station with the corresponding regulation. Instead, they can internalize a new behavioral regulation relatively quickly 
at any point on the continuum, depending on their previous experiences and current situational factors (Ryan and Deci 2000). It is assumed that there are three internal psychological needs that form the basis for self-motivation and support the process of internalization (Ryan and Deci 2000, 2020), as follows:

1. Relatedness is the need to feel belonging and connectedness. This behavior is exemplified, requested, or valued by significant others (Ryan and Deci 2000, 2020). Relatedness is a social mechanism of perception that promotes self-esteem and encourages individual initiative (Wilkesmann and Schmid 2014). A person adopts the social norms of the group to which they feel part of. Social norms can only guide action when they have been internalized, and thus trigger an internalized or intrinsic form of motivation.

2. Autonomy is related to the intention to experience oneself as self-organized and to be able to act according to one's own will (Ryan and Deci 2013). This need is also linked to the need for individual freedom and to feel responsible for one's own behavior (Tang et al. 2020).

3. Competence is related to the fact that people are more likely to exhibit behaviors that are valued by relevant social groups when they feel effective with regard to these activities (Ryan and Deci 2000). Perception of competence is undermined if feedback is negative or challenges are not perceived as optimal (Ryan and Deci 2013). Only when a person is recognized as competent are they able to fully internalize external goals (Wilkesmann and Schmid 2014). A perception of incompetence leads to a feeling of being overloaded and causes amotivation.

In the following section, we will discuss the relationship between teaching motivation in continuing higher education and SDT.

\subsection{Teaching motivation in continuing higher education and self-determination theory}

Some studies can be found on the teaching motivation of professors in traditional undergraduate and graduate teaching (Wilkesmann and Lauer 2020; Wilkesmann and Schmid 2012), or in online distance education (Maguire 2005). The central finding of these studies is that university staff are very highly intrinsically motivated and very low extrinsically motivated in teaching. Several studies have used SDT to analyze student motivation of non-traditional students (Völkening et al. 2010; Johnson et al. 2016). However, there is no empirical investigation of teaching motivation in continuing higher education in Germany. Although the transferability of the SDT model has been confirmed for professors who teach (Wilkesmann and Schmid 2014), it cannot be applied one-to-one to continuing higher education for an in-depth analysis. Therefore, we conducted expert interviews with continuing higher education teachers and analyzed the result with the help of the content analysis (Mayring 2015). The result of the analyses led to an extension of the SDT in the area of extrinsic motivation, namely by the three facets of "knowledge transfer into practice", "contact with practice" and "remaining in academia" (Wilkesmann et al. 2020a, p. 190). However, a study on the transferability of SDT to teaching motivation in the field of continuing higher education has not yet been conducted. 
Relatedness is a psychological need that supports the process of internalization and also includes the relationship of an individual to the peer group to which they feel part of. This is important because it determines the individual's behavior by the social norms that apply within the peer group (Wilkesmann et al. 2020a). Applied to the case of continuing higher education faculty, the peer group represents the community of continuing higher education. Because teaching in continuing higher education is voluntary, few university faculty members participate. Precisely because they are few in number, they form a community of their own. This community is characterized by a high degree of homogeneity in its internal orientation and can therefore be understood as a subcultural scene (Schmid 2018). Therefore, the commitment to continuing higher education can also be understood by belonging to this scene. The peer group of continuing higher education faculty is characterized by the fact that common norms and values are shared with regard to basic higher education policy orientations. Continuing higher education is not only attributed a general significance but is also a pioneering role in higher education development in the HES in Germany. Continuing higher education takes up important impulses from practice and transfers them into the university (Wilkesmann 2010). In addition, the faculty who are active in continuing higher education serve as pioneers of a new university didactics and as initiators of university reforms (Wilkesmann et al. 2020a). With regard to attitudes and teaching motivations, it was found that the faculty who teach in continuing higher education do not differ fundamentally in their most important attitudes towards continuing higher education and its teaching motivations. Consequently, Wilkesmann et al. (2020a) conclude that continuing higher education faculty form a homogeneous group in terms of their attitudes, values, and motivation. University faculty in continuing higher education believe that universities should be more open to the demands and expectations of working students in continuing higher education. Additionally, they think that teaching in continuing higher education is a source of inspiration for new research questions. Furthermore, the didactics of continuing education is an example and a source of inspiration for teaching in undergraduate programs. That's why they believe continuing higher education is a future vision for undergraduate teaching. Averill and Major (2020) are investigating the research question of what higher educators motivate to innovate. With the theoretical underpinning of SDT they show that developing relatedness between higher education teachers and students reported as motivators for innovative teaching. The feeling of belonging to the group of continuing higher educators increases the acceptance of the values that exist in this group. Deci and Ryan (2014) emphasize that not all relationships contribute to relatedness. Only relationships in which all partners experie nce autonomy and provide autonomy support to the other are deeply satisfying of the need for relatedness. In Germany, continuing higher education is very often organized in centralized academic units (Maschwitz et al. 2020), which are usually staffed by faculty who organize continuing higher education and who establish and maintain close contacts with the professors who teach in continuing higher education. Regular meetings of the teachers in continuing higher education are organized, where they exchange information about the program development and there teaching experience. Since this is organized in voluntary network 
relationships, they are characterized by a reciprocal high autonomy. This leads to our first hypotheses:

H1a A stronger perception of relatedness will lead to higher intrinsic motivation.

H1b A stronger perception of relatedness will lead to lower extrinsic motivation.

Perception of autonomy and competence can be assumed for the investigated group. Continuing higher education for the university faculty is optional-neither the dean nor anyone else can force a university faculty member to teach in continuing higher education. The mandatory teaching load only includes traditional undergraduate and graduate teaching. Consequently, the university faculty members who are involved in continuing higher education do so voluntarily. We can always assume autonomy with this because it is their free choice (Ryan and Deci 2020; for more detail on the correlation between autonomy and motivation by students see Wong et al. 2020). It is crucial for faculty to be aware of their teaching competencies to be able to teach well (Smolikevych 2019). If faculty in continuing higher education realize that their own competences do not suffice to reflect the practical experiences of the students on a scientific level, then they perceive themselves as overloaded and as not self-determined. This has a negative effect on the psychological need for competence, which in turn hinders the process of internalization. Orazbayeva et al. (2021) give empirical evidence that autonomy, relatedness, and competence facilitating academic engagement in education driven university-business cooperation, which is related to continuing higher education because the latter is often also a university-business cooperation. Salikhova et al. (2020) give a literature review about SDT and digital learning, especially the influence of autonomy, relatedness, and competence to predict student academic success in the field of digital education. Lavina et al. (2020) provide some empirical evidence for communication technology competency and motivation in continuing higher education. It can be assumed that people who have been teaching at continuing higher education are very familiar with the special challenges and the way of dealing with continuing higher education students because they are doing it by their own choice. If these participants still take up a teaching position in continuing higher education, then it can be assumed that they perceive themselves as competent. Anyone who feels overwhelmed by continuing higher education teaching will not volunteer for it. Organizational support is another important prerequisite for motivation, which will be discussed in the next section.

\subsection{Organizational resources}

All action takes place in situations. In the case of continuing higher education, the situation is characterized by the organizational resources of the university. Therefore, in addition to the basic needs, the prerequisite of acting through the organizational resources must also be considered. However, when someone is teaching in continuing higher education, then it is important that they should also have access to sufficient resources. Otherwise, they will not have the means to achieve their goals. Therefore, resources are central to the perception of autonomy. Basically, a university faculty 
member only engages in continuing higher education teaching if sufficient human and financial resources are provided by the university. Likewise, the administrative organization of teaching must be supported. Ryan and Deci (2020) provide an overview of empirical studies that analyze the relationship between perceptions of organizational structures and (school) teacher motivation. Consistent with Pelletier et al. (2002), these studies all find that teaching motivation will be more external when the structural constraints are tighter. If clear instructions for action exist and the actors' room for maneuver is small, their motivation tends to be extrinsic. The actors only follow the instructions and do not develop an intrinsically motivated initiative. Similarly, a relationship can be found between university faculty motivation and student learning motivation (King and Bunce 2020). The important link between organizational support and motivation is also postulated by Rich et al. (2010), who are of the opinion that intrinsic motivation can be predicted by perceived organizational support. When the employee perceives low organizational support, then they tend to be unsure of what to expect and also fear that they will suffer for their personal engagement. Consequently, they begin to diverge themselves from their roles to protect themselves. Employees can be given an opportunity to feel organizational support in a working environment that has human resources and equipment. Shuck et al. (2018) claim that employees who perceive their working environment to be and positive tend to be motivated by internalized forms of motivation because they see the importance and value of their work, and they feel supported by their supervisors. Resources can include contemporary furniture and also advanced technologies (Sass 2019). Therefore, our second hypotheses are as follows:

H2a Intrinsic motivation will be higher when the perception of resources for goal achievement is higher.

H2b Extrinsic motivation will be higher when the perception of resources for goal achievement is higher.

In addition to these four hypotheses, the effect of some control variables on intrinsic and extrinsic motivation is also of interest. Therefore, the variables of number of scientific status, age, gender, type of university, and discipline will also be included.

\section{Methodology}

\subsection{Research design}

We used a secondary data analysis to test our hypotheses. The original dataset was obtained through two surveys and three different access methods. The field phase of the first survey covered the period from April to June 2017 and initially interviewed university faculty from the projects ("Advancement through education: open universities; Aufstieg durch Bildung: offene Hochschulen”). Contact with continuing higher education faculty took place via emails to the project managers and coordinators, who were asked to forward the email to all university faculty. The first survey 
produced an adjusted net sample of 231 continuing higher education faculty. The field phase of the second survey took place from March to December 2018. Within the first access, members of the German Society for Continuing Higher Education and Distance Learning (DGWF) were asked to forward the email to the faculty in their university. For the second access, the survey was advertised at conferences, in the workspace of the above-mentioned project, and on the blog of the Network Open Universities (NOH) in Germany. For the third access, all of the leaders of continuing higher education programs at German universities were contacted, who were also asked to forward the email to faculty. In all surveys, participation was voluntary; there were no additional incentives for completing the questionnaire. All respondents were assured of anonymity. In total, the net sample of the second survey is 318 participants. Thus, the total sample of the two surveys consists of 549 respondents. Unfortunately, we cannot calculate a response rate because we do not know the basic population of all university faculty members who are engaged in continuing higher education in Germany.

\subsection{Participants}

The survey participants were on average 49 years old, $65.3 \%$ were male and $34.7 \%$ were female. Furthermore, $42.3 \%$ of the respondents are professors.

Since there is no random selection in the strict sense, we cannot claim that the sample is representative of teachers in continuing higher education in Germany but we can compare it with the population of all university faculty engaged in undergraduate and graduate teaching.

Table 1 provides an overview of the characterization of the respondent sample. Thus, a first hint can be given to the question of what constitutes the persons who participate in teaching in continuing higher education. The column on the far right characterizes the sample, and the column before that characterizes those involved in undergraduate and graduate teaching. The data on undergraduate and graduate teaching come from the Federal Statistical Office (Destatis) and describe all university faculty at public universities who are financed by budgetary funds. Academic staff employed via the budget always have to provide undergraduate and graduate teaching by contract. In this respect, these data can be used to compare all persons engaged in undergraduate and graduate teaching with our sample, which includes persons engaged in the teaching of continuing higher education. The data used from the Federal Statistical Office represent the university faculty at universities in 2017 (Statistisches Bundesamt [Destatis] 2018).

The comparison shows that in continuing higher education, most university faculty come from law, economics and social sciences, followed by engineering and humanities. In the area of undergraduate and graduate teaching, the largest group of teachers comes from human medicine and health sciences, followed by engineering and mathematics and natural sciences.

The employment relationships are also different: in continuing higher education, the largest group of teachers are professors, followed by teachers for special tasks and honorary staff and research assistants. In undergraduate teaching, the largest 
Table 1 Employment relationship and subject affiliation (Wilkesmann et al. 2020b, p. 174-175)

\begin{tabular}{|c|c|c|c|c|c|}
\hline \multicolumn{2}{|c|}{$\begin{array}{l}\text { Full-time university faculty } \\
\text { Employment relationship and professional affilia- } \\
\text { tion }\end{array}$} & \multicolumn{2}{|c|}{$\begin{array}{l}\text { University faculty in } \\
\text { undergraduate and } \\
\text { graduate teaching }\end{array}$} & \multicolumn{2}{|c|}{ Sample } \\
\hline & & $N$ & $\%$ & $N$ & $\%$ \\
\hline \multirow[t]{6}{*}{$\overline{\text { Total }}$} & Professors & 47,568 & 19.07 & 209 & 42.3 \\
\hline & Lecturers and assistants & 3520 & 1.41 & 7 & 1.4 \\
\hline & Scientific staff & 188,047 & 75.37 & 85 & 17.2 \\
\hline & Teachers for special tasks & 10,351 & 4.15 & 96 & 19.4 \\
\hline & Honorary staff & - & - & 78 & 15.8 \\
\hline & Total & 249,486 & 100 & 494 & 100 \\
\hline \multirow[t]{6}{*}{ Humanities } & Professors & 4673 & 23.35 & 14 & 16.6 \\
\hline & Lecturers and assistants & 358 & 1.79 & 3 & 3.6 \\
\hline & Scientific staff & 12,630 & 63.12 & 29 & 34.2 \\
\hline & Teachers for special tasks & 2350 & 11.74 & 20 & 23.5 \\
\hline & Honorary staff & - & - & 17 & 20 \\
\hline & Total & 20,011 & 8.02 & 85 & 17.4 \\
\hline \multirow{6}{*}{$\begin{array}{l}\text { Law, economics } \\
\text { and social } \\
\text { sciences }\end{array}$} & Professors & 14,005 & 32.52 & 81 & 44 \\
\hline & Lecturers and assistants & 1355 & 3.15 & 3 & 1.6 \\
\hline & Scientific staff & 24,890 & 57.80 & 24 & 13 \\
\hline & Teachers for special tasks & 2813 & 6.53 & 33 & 18 \\
\hline & Honorary staff & - & - & 34 & 18.5 \\
\hline & Total & 43,063 & 17.26 & 184 & 37.7 \\
\hline \multirow[t]{6}{*}{ Engineering } & Professors & 12,386 & 24.57 & 77 & 67.6 \\
\hline & Lecturers and assistants & 344 & 0.68 & 0 & 0 \\
\hline & Scientific staff & 36,833 & 73.08 & 11 & 9.6 \\
\hline & Teachers for special tasks & 841 & 1.67 & 15 & 13.2 \\
\hline & Honorary staff & - & - & 11 & 9.6 \\
\hline & Total & 50,404 & 2020 & 114 & 23.4 \\
\hline \multirow[t]{6}{*}{ Sports } & Professors & 267 & 1371 & 1 & 6.7 \\
\hline & Lecturers and assistants & 8 & 0.41 & 0 & 0 \\
\hline & Scientific staff & 1284 & 65.91 & 8 & 53.3 \\
\hline & Teachers for special tasks & 389 & 19.97 & 2 & 13.4 \\
\hline & Honorary staff & - & - & 1 & 6.7 \\
\hline & Total & 1948 & 0.78 & 15 & 3.1 \\
\hline \multirow{6}{*}{$\begin{array}{l}\text { Mathematics, } \\
\text { natural sciences }\end{array}$} & Professors & 6420 & 14.42 & 22 & 47.9 \\
\hline & Lecturers and assistants & 464 & 1.04 & 1 & 2.2 \\
\hline & Scientific staff & 36,804 & 82.68 & 4 & 8.7 \\
\hline & Teachers for special tasks & 824 & 1.85 & 11 & 23.9 \\
\hline & Honorary staff & - & - & 7 & 15.2 \\
\hline & Total & 44,512 & 17.84 & 46 & 9.4 \\
\hline \multirow{5}{*}{$\begin{array}{l}\text { Human medicine, } \\
\text { health sciences }\end{array}$} & Professors & 4158 & 6.81 & 8 & 24.2 \\
\hline & Lecturers and assistants & 674 & 1.10 & 0 & 0 \\
\hline & Scientific staff & 56,097 & 91.88 & 5 & 15.2 \\
\hline & Teachers for special tasks & 127 & 0.21 & 13 & 39.4 \\
\hline & Honorary staff & - & - & 5 & 15.2 \\
\hline
\end{tabular}


Table 1 (Continued)

\begin{tabular}{|c|c|c|c|c|c|}
\hline \multicolumn{2}{|c|}{$\begin{array}{l}\text { Full-time university faculty } \\
\text { Employment relationship and professional affilia- } \\
\text { tion }\end{array}$} & \multicolumn{2}{|c|}{$\begin{array}{l}\text { University faculty in } \\
\text { undergraduate and } \\
\text { graduate teaching }\end{array}$} & \multicolumn{2}{|c|}{ Sample } \\
\hline & & $N$ & $\%$ & $N$ & $\%$ \\
\hline \multirow{6}{*}{$\begin{array}{l}\text { Agricultural, } \\
\text { forestry and } \\
\text { nutritional } \\
\text { sciences, } \\
\text { veterinary } \\
\text { medicine }\end{array}$} & Total & 61,056 & 24.47 & 33 & 6.8 \\
\hline & Professors & 1202 & 19.23 & 4 & 44.4 \\
\hline & Lecturers and assistants & 47 & 0.75 & 0 & 0 \\
\hline & Scientific staff & 4868 & 77.88 & 3 & 33.3 \\
\hline & Teachers for special tasks & 134 & 2.14 & 1 & 11.1 \\
\hline & Honorary staff & - & - & 1 & 11.1 \\
\hline \multirow{7}{*}{ Art, Art science } & Total & 6251 & 2.51 & 9 & 1.8 \\
\hline & Professors & 3734 & 51.21 & 0 & 0 \\
\hline & Lecturers and assistants & 173 & 2.37 & 0 & 0 \\
\hline & Scientific staff & 2406 & 33.0 & 0 & 0 \\
\hline & Teachers for special tasks & 978 & 13.41 & 1 & 50 \\
\hline & Honorary staff & - & - & 0 & 0 \\
\hline & Total & 7291 & 2.92 & 2 & 0.4 \\
\hline
\end{tabular}

group is the research assistants, followed by the professors, and the smallest group is the teaching faculty for special tasks.

Another important difference not shown in Table 1 is the distribution among university types. In the sample, $55.4 \%$ of all respondents teach at a university of applied sciences, while $44.6 \%$ are employed at a research university. In the basic population of all university faculty $14.1 \%$ are teaching at universities of applied sciences and $82.6 \%$ are teaching at research universities. Thus, in our sample, many more university faculty from universities of applied sciences teach in continuing higher education than in undergraduate and graduate programs relative to university faculty from research universities.

\subsection{Measurement}

\subsubsection{Dependent variables}

The dependent variables in our study are intrinsic motivation (M 4.0) and extrinsic motivation (M 2.7), each of which is related to SDT. Extrinsic motivation here refers to the opportunity to earn extra money. The following tables list the items that were used to operationalize the individual forms of motivation. All items were measured using a five-point Likert scale ( $1=$ strongly disagree; $5=$ strongly agree) (Table 2 ).

\subsubsection{Independent variables}

The independent variables that were used in our study include relatedness and resources. For Hypotheses $1 \mathrm{a}$ and $1 \mathrm{~b}$, relatedness was measured using three items (see Table 3) (principal component analysis, KMO value $0.803 ; \alpha 0.75$ ). All items were measured using a five-point Likert scale ( $1=$ strongly disagree; $5=$ strongly agree). 
Table 2 Intrinsic and extrinsic motivation survey items

$\begin{aligned} & \text { Why or for what purpose do you teach in continuing higher } \\ & \text { education? Or, what is your teaching motivation in continu- }\end{aligned}$
ing higher education?

For Hypotheses $2 \mathrm{a}$ and $2 \mathrm{~b}$, the provision and support with resources have been measured with the following items (see Table 4 and 5) (principal component analysis, $\mathrm{KMO}$ value $0.70 ; \alpha 0.82$ ). All items were measured using a five-point Likert scale ( 1 = strongly disagree; 5 = strongly agree).

The control variables include the scientific status of professors versus lecturers or scientific assistants, age and gender $(1=$ female; $0=$ male $)$, and the variable of type of university $(1=$ research university; $0=$ university of applied sciences). Additionally, the disciplines have been integrated as control variables. Reference variable is law, economics and social sciences. We did not use sports, art, and agricultural sciences due to the small numbers in the sample.

The correlation table shows that extrinsic motivation and organizational resources (positive) as well as age (negative) have a significant correlation. Additionally, intrinsic motivation and relatedness as well as organizational resources have a significant positive correlation and intrinsic motivation and age a significant negative correlation.

The mean value comparison shows that teachers in continuing higher education are more likely to be intrinsically motivated, with professors are more extrinsically motivated than other university faculty for teaching in continuing higher education. The female university faculty is more intrinsically motivated than male university faculty. Teachers at the university of applied sciences are more extrinsically motivated than teachers at the research university. There is also a difference between disciplines in teaching motivation in continuing higher education. Respondents from medicine and health science are significant less extrinsically motivated than all oth- 
Table 3 Relatedness and resources survey items

\begin{tabular}{|c|c|c|c|c|}
\hline & $N$ & $\mathrm{M}$ & STD & Cr. $\alpha$ \\
\hline \multicolumn{5}{|l|}{ Relatedness } \\
\hline $\begin{array}{l}\text { Universities should be open to the demands and expecta- } \\
\text { tions of (mostly working) students in continuing higher } \\
\text { education }\end{array}$ & 481 & 4.0 & 0.9 & 0.75 \\
\hline $\begin{array}{l}\text { Universities should use continuing higher education as } \\
\text { a source of inspiration for research questions of practical } \\
\text { relevance }\end{array}$ & 481 & 4.1 & 1.0 & \\
\hline $\begin{array}{l}\text { Universities should use the didactics of continuing higher } \\
\text { education as a source of inspiration for undergraduate } \\
\text { teaching }\end{array}$ & 465 & 3.9 & 1.0 & \\
\hline \multicolumn{5}{|l|}{ Resources } \\
\hline $\begin{array}{l}\text { I receive administrative support for my continuing higher } \\
\text { education teaching }\end{array}$ & 497 & 3.4 & 1.4 & 0.82 \\
\hline $\begin{array}{l}\text { We are adequately staffed to provide continuing higher } \\
\text { education }\end{array}$ & 442 & 2.8 & 1.3 & \\
\hline $\begin{array}{l}\text { We are adequately equipped with material resources to } \\
\text { provide continuing higher education }\end{array}$ & 461 & 3.1 & 1.2 & \\
\hline
\end{tabular}

Table 4 Correlations of all variables

\begin{tabular}{|c|c|c|c|c|c|}
\hline & $\begin{array}{l}\text { Extrinsic moti- } \\
\text { vation }\end{array}$ & $\begin{array}{l}\text { Intrinsic moti- } \\
\text { vation }\end{array}$ & Relatedness & $\begin{array}{l}\text { Organizational } \\
\text { resources }\end{array}$ & Age \\
\hline $\begin{array}{l}\text { Extrinsic motiva- } \\
\text { tion }\end{array}$ & - & -0.023 & -0.063 & $0.129 * *$ & $-0.115^{*}$ \\
\hline $\begin{array}{l}\text { Intrinsic motiva- } \\
\text { tion }\end{array}$ & -0.023 & - & $0.113^{*}$ & $0.140 * *$ & $-0.157 * *$ \\
\hline Relatedness & -0.063 & $0.113^{*}$ & - & 0.006 & $0.105^{*}$ \\
\hline $\begin{array}{l}\text { Organizational } \\
\text { resources }\end{array}$ & $0.129 * *$ & $0.140 * *$ & 0.006 & - & -0.049 \\
\hline Age & $-0.115 *$ & $-0.157 * *$ & $0.105^{*}$ & -0.049 & - \\
\hline
\end{tabular}

$* p<0.05, * * p<0.01$

Table 5 Means value comparison

\begin{tabular}{lll}
\hline & Extrinsic motivation & Intrinsic motivation \\
\hline Professors & $2.90^{*}$ & 3.94 \\
All others & $2.61^{*}$ & 4.08 \\
Female & 2.56 & $4.20^{* *}$ \\
Male & 2.79 & $3.95^{* *}$ \\
Research University & $2.54^{* *}$ & 4.04 \\
University of Applied Sciences & $2.86^{* *}$ & 4.03 \\
Disciplines & & \\
Engineering, Natural Sciences & 2.80 & $3.81^{* *}$ \\
Humanities & 2.52 & 4.18 \\
Medicine, Health Sciences & $2.22^{*}$ & 4.14 \\
Law, Economics, Social Scienes & 2.84 & 4.11 \\
\hline
\end{tabular}


ers. Participants from Engineering and natural sciences are less intrinsically motivated in teaching for continuing higher education than all others.

\section{Empirical results}

Linear regressions were calculated for extrinsic motivation and intrinsic motivation. The results are shown in Table 6.

Hypothesis 1a (a stronger perception of relatedness will lead to higher intrinsic motivation) is supported. The effect strength of relatedness on intrinsic motivation is positive and strong. Hypothesis $1 \mathrm{~b}$ (a stronger perception of relatedness will lead to lower extrinsic motivation) cannot be supported in principle. Hypothesis 2 a (intrinsic motivation will be higher when the perception of resources for goal achievement is higher) is supported. Hypothesis $2 \mathrm{~b}$ (extrinsic motivation will be higher when the perception of resources for goal achievement is higher) is supported.

With regard to the control variables that we used, it can be seen that the academic status is related to extrinsic motivation. Professors are more extrinsically motivated than other faculty. Age and extrinsic motivation are negatively related, which means that older people are less extrinsically motivated. The older faculty are more intrinsically motivated. There is a positive relationship between gender and intrinsic motivation, suggesting that women are more intrinsically motivated. The variables of university type, extrinsic motivation and intrinsic motivation are not significantly related. University faculty in medicine and health sciences is less extrinsically mo-

Table 6 Factors influencing extrinsic and intrinsic motivation in continuing higher education

\begin{tabular}{|c|c|c|}
\hline & $\begin{array}{l}\text { Extrinsic } \\
\text { motivation }\end{array}$ & $\begin{array}{l}\text { Intrinsic } \\
\text { motivation }\end{array}$ \\
\hline \multicolumn{3}{|l|}{ H1 } \\
\hline Relatedness & -0.019 & $0.370 * *$ \\
\hline \multicolumn{3}{|l|}{ H2 } \\
\hline Organizational resources & $0.203 * *$ & $0.171 * *$ \\
\hline \multicolumn{3}{|l|}{ Control variables } \\
\hline $\begin{array}{l}\text { Professors } \\
(1=\text { Professors; } 0=\text { all others })\end{array}$ & $0.182 * *$ & -0.032 \\
\hline Age & $-0.156 * *$ & $0.124 * *$ \\
\hline $\begin{array}{l}\text { Gender } \\
(1=\text { female } ; 0=\text { male })\end{array}$ & -0.015 & $0.136^{*}$ \\
\hline $\begin{array}{l}\text { University type } \\
\text { ( } 1=\text { Research University; } 0=\text { University of Applied Sci- } \\
\text { ences) }\end{array}$ & -0.036 & -0.048 \\
\hline \multicolumn{3}{|c|}{ Disciplines (reference category Law, Economics, Social Sciences) } \\
\hline Engineering, Natural Science & -0.022 & -0.050 \\
\hline Humanities & 0.011 & 0.014 \\
\hline Medicine, Health Science & $-0.155 * *$ & -0.067 \\
\hline$N$ & 355 & 362 \\
\hline Corr. $R^{2}$ & 0.086 & 0.194 \\
\hline
\end{tabular}

$* p<0.05, * * p<0.01$ 
tivated than the university faculty in law, economics, and social science with regard to teaching in continuing higher education.

\section{Discussion}

Our research question asked: Do perceived relatedness and organizational resources influence teaching motivation in continuing higher education? In general, it should be noted that most university faculty are intrinsically motivated rather than extrinsically motivated to teach in continuing higher education (Table 4 and 5). This is in line with empirical findings from undergraduate and graduate education (Wilkesmann and Lauer 2020; Wilkesmann and Schmid 2012). It is not surprising that strong relatedness increases intrinsic motivation-if individuals feel part of and connected to the peer group of continuing higher education faculty, then their need for social embedding is fulfilled (Deci and Ryan 2014). The members of the community exemplify teaching in continuing higher education and in turn they appreciate it in the other community members. The process of internalization is supported by the fulfillment of the psychological need, hence the motivation can take on an intrinsic form. Finally, teaching in continuing higher education gives pleasure to these individuals and they feel themselves to be innovative pioneers in teaching with a special group of students. This result supports the statement that university faculty in the continuing higher education form their own subcultural scene (Schmid 2018) as cross-border commuters in the HES (Wilkesmann 2010). For this university faculty, continuing higher education and contact with practice is a value in its own, which is given higher priority than an academic career.

There are several interpretations of the statement that strong relationality does not lead to a significantly lower extrinsic motivation. When an individual is extrinsically motivated, they want to achieve an objective with their performance that can be separated from the action itself. For example, they want to have a selective incentive for their actions. The relatedness in the community of continuing higher education faculty may already be so advanced that the values already agree with the own self and outweigh the other extrinsic motives. Another explanation is that individuals teach in continuing higher education for different reasons and therefore have different forms of motivation. Thus, it is conceivable that an individual has internalized the values through the community, but at the same time other reasons are added. Finally, the additional monetary earnings that can be achieved in continuing higher education can be seen as attractive and are always used as an argument to recruit new university faculty. There is potentially the danger of the crowding-out effect, i.e. the intrinsic motivation can possibly be crowded out by the extrinsic motivation (Frey 1997). On the one hand, SDT itself claims that the process of internalization is not a step-bystep model where each step has to be strictly followed; on the other hand, SDT says that people can be both intrinsically and extrinsically motivated, in different ways and for different types of action.

Organizational resources support both types of motivation. This relation is understandable because each support with adequate means simplifies the goal achievement and thus strengthens the motivation for the goal achievement. Given that continuing 
higher education is an additional effort, resource support is a particularly important aspect. With the right resources, the organization has an important, indirect governance instrument at its disposal to promote continuing higher education.

Professors in Germany can be considered to be civil servants with an unlimited contract. It is consequently interesting to note that additional earnings have an important incentive function for this group. This could lead to the assumption that professors are at the end of their academic careers and are therefore no longer so interested in research, but would rather wish to earn more money by teaching in continuing higher education. However, this assumption is wrong, as can be seen from the angle of age. Older university faculty in particular are less extrinsically and more intrinsically motivated. The fact that women are more intrinsically motivated is also consistent with the findings of other contributions for traditional undergraduate teaching (Wilkesmann and Lauer 2020).

It is also interesting to note that continuing higher education takes place more often at universities of applied sciences than at research universities. This can be explained by the fact that professors at universities of applied sciences come from the business world and are therefore closer to business and industry than professors at research universities.

In summary, we can state that university faculty are especially intrinsically motivated to teach in continuing higher education when they perceive high relatedness. This is in line with findings from undergraduate and graduate teaching (Wilkesmann and Lauer 2020). Thus, the university can increase the likelihood of intrinsic teaching motivation among its members when they have the opportunity to form communities where they share common social norms and organizational support is offered. The optional action of the members can thus be governed by the fact that corresponding norms prevail.

\section{Limitations and future research}

The main limitation of this study is that it only refers to continuing higher education in Germany. However, given that the HES in Germany differs fundamentally from almost all other countries in this respect, this restriction cannot be avoided. Only a comparison with Austria, Switzerland or the Netherlands would make sense.

It is recommended that future research should compare the motivation to teach in continuing higher education with the motivation to teach in traditional undergraduate education to analyze the extent to which teaching in continuing higher education is a special case. In addition, a longitudinal study would be able to reveal whether the age effect refers to the professional situation until retirement or if it is an effect of experience. In particular, is an extra income important for younger university faculty because they have less money or does the importance of an extrinsic incentive fade over time? This question can only be answered in a longitudinal view. 
Funding This work was supported by the German Federal Ministry of Education and Research $(\mathrm{BMBF})$ under the joint Federal Government Grant "Advancement through education: open universities" (01.03.2016-31.12.2020). The BMBF has not influenced the results. The results and interpretations presented in this publication are the sole responsibility of the authors

Open Access funding enabled and organized by Projekt DEAL.

Open Access This article is licensed under a Creative Commons Attribution 4.0 International License, which permits use, sharing, adaptation, distribution and reproduction in any medium or format, as long as you give appropriate credit to the original author(s) and the source, provide a link to the Creative Commons licence, and indicate if changes were made. The images or other third party material in this article are included in the article's Creative Commons licence, unless indicated otherwise in a credit line to the material. If material is not included in the article's Creative Commons licence and your intended use is not permitted by statutory regulation or exceeds the permitted use, you will need to obtain permission directly from the copyright holder. To view a copy of this licence, visit http://creativecommons.org/licenses/by/4.0/.

\section{References}

Averill, R.M., \& Major, J. (2020). What motivates higher education educators to innovate? Exploring competence, autonomy, and relatedness-And connections with wellbeing. Educational Research, 62(2), 146-161.

Berghaeuser, H., \& Hoelscher, M. (2020). Reinventing the third mission of higher education in Germany: political frameworks and universities' reactions. Tertiary Education and Management, 26, 57-76. https://doi.org/10.1007/s11233-019-09030-3.

Cendon, E. (2019). Connecting theory and practice in higher education in Germany. In J. Talbot (Ed.), Global perspectives on work-based learning initiatives (pp. 84-113). Hershey: IGI Global.

Daumiller, M., Stupnisky, R., \& Janke, S. (2020). Motivation of higher education faculty: theoretical approaches, empirical evidence, and future directions. International Journal of Educational Research, 99, 101502. https://doi.org/10.1016/j.ijer.2019.101502.

Deci, E.L., \& Ryan, R.M. (2014). Autonomy and need satisfaction in close relationships: relationships motivation theory. In Human motivation and interpersonal relationships: theory, research, and applications (pp. 53-73). https://doi.org/10.1007/978-94-017-8542-6_3.

Donald, J. N., Bradshaw, E. L., Ryan, R. M., Basarkod, G., Ciarrochi, J., Duineveld, J. J., Guo, J., \& Sahdra, B. K. (2019). Mindfulness and its association with varied types of motivation: a systematic review and meta-analysis using self-determination theory. Personality and Social Psychology Bulletin, 46(1), 1121-1138. https://doi.org/10.1177/0146167219896136.

Drzymala, D. (2005). Ressourcenmanagement zur Bewältigung der steigenden und sich stetig verändernden Anforderungen in der Arbeitswelt. München: GRIN. https://www.grin.com/document/63475. Accessed 13 May 2021.

Franz, M., \& Feld, T.C. (2015). The status of continuing higher education at German universities: a metaphor analysis. Journal of Adult and Continuing Education, 21(2), 77-92.

Frey, B. S. (1997). Not just for the money. An economic theory of personal motivation. Cheltenham: Edward Elgar.

Hagger, M.S., \& Hamilton, K. (2020). General causality orientations in self-determination theory: metaanalysis and test of a process model. European Journal of Personality. https://doi.org/10.1177/ 0890207020962330.

Hüther, O., \& Krücken, G. (2018). Higher education in Germany: recent developments in an international perspective. Cham: Springer.

Johnson, M.L., Taasoobshirazi, G., Clark, L., Howell, L., \& Breen, M. (2016). Motivations of traditional and nontraditional college students: from self-determination and attributions, to expectancy and values. The Journal of Continuing Higher Education, 64(1), 3-15.

Khiat, H. (2017). Academic performance and the practice of self-directed learning: the adult student perspective. Journal of Further and Higher Education, 41(1), 44-59.

King, N., \& Bunce, L. (2020). Academics' perceptions of students' motivation for learning and their own motivation for teaching in a marketized higher education context. British Journal of Educational Psychology, 90(3), 790-808. 
Lavina, T. A., Zakharova, A. N., Aleksandrov, A. H., \& Talanova, T. V. (2020). Professional competencies of a higher education teacher in an information educational environment. Advances in Social Science, Education and Humanities Research, 437, 262-269. https://doi.org/10.2991/assehr.k.200509.048.

Lenhardt, G., Reisz, R. D., \& Stock, M. (2012). Überlebenschancen privater und öffentlicher Hochschulen im Ländervergleich. Beiträge zur Hochschulforschung, 34(2), 30-48.

Lim, D.H., You, J., Kim, J., \& Hwang, J. (2019). Instructional design for adult and continuing higher education: theoretical and practical considerations. In Y. Vovides \& L. R. Lemus (Eds.), Optimizing instructional design methods in higher education (pp. 73-100). Hershey: GI Global.

Maguire, L. L. (2005). Literature review: faculty participation in online distance education: barriers and motivators. Online Journal of Distance Learning Administration, 8(1), 1-16.

Maschwitz, A., Speck, K., Schwabe, G., \& Amintavakoli, R. (2020). Organisationale Verankerung wissenschaftlicher Weiterbildung an Hochschulen. In E. Cendon, U. Wilkesmann, A. Maschwitz, S. Nickel, K. Speck \& U. Elsholz (Eds.), Wandel an Hochschulen? (pp. 233-257). Münster: Waxman.

Mayring, P. (2015). Qualitative content analysis: theoretical background and procedures. In Approaches to qualitative research in mathematics education (pp. 365-380). Dordrecht: Springer.

Mintzberg, H. (2004). Managers not MBAs. London, New York: FT Prentice Hall.

Mörth, A. (2020). Quality management in German higher education: approaches and challenges in university continuing education. In W. Nuninger \& J.-M. Chatelet (Eds.), Handbook of research on operational quality assurance in higher education for life-long learning (pp. 1-26). Hershey: IGI Global.

Orazbayeva, B., Sijde, P. van der, \& Baaken, T. (2021). Autonomy, competence and relatedness - The facilitators of academic engagement in education-driven university-business cooperation. Studies in Higher Education, 46(7), 1406-1420.

Pelletier, L. G., Seguin-Lévesqui, C., \& Legault, L. (2002). Pressure from above and pressure from below as determinants of teachers' motivation and teaching behavior. Journal of Educational Psychology, 94, 186-196.

Rich, B.L., LePine, J.A., \& Crawford, E.R. (2010). Job engagement: antecedents and effects on job performance. Academy of Management Journal, 53(3), 617-635.

Ryan, R.M., \& Deci, E.L. (2000). Self-determination theory and the facilitation of intrinsic motivation, social development and well-being. American Psychologist, 55(1), 68-78.

Ryan, R. M., \& Deci, E.L. (2013). Toward a social psychology of assimilation: self-determination theory in cognitive development and education. In B. W. Sokol, F. M. E. Grouzet \& U. Müller (Eds.), Selfregulation and autonomy: social and developmental dimensions of human conduct (pp. 191-207). Cambridge: Cambridge University Press.

Ryan, R. M., \& Deci, E.L. (2020). Intrinsic and extrinsic motivation from a self-determination theory perspective: definitions, theory, practices, and future directions. Contemporary Educational Psychology, 61, 101860. https://doi.org/10.1016/j.cedpsych.2020.101860.

Salikhova, N. R., Lynch, M. F., \& Salikhova, A. B. (2020). Psychological aspects of digital learning: a selfdetermination theory perspective. Contemporary Educational Technology. https://doi.org/10.30935/ cedtech/8584.

Sass, E. (2019). Mitarbeitermotivation, Mitarbeiterbindung. Was erwarten Arbeitnehmer? Wiesbaden: Gabler.

Schmid, C. J. (2018). Wissenschaftliche Weiterbildung: Irgendwie subkulturell/szenisch? Blog Netzwerk Offene Hochschulen. https://de.netzwerk-ohs.uni-oldenburg.de/noh/noh_blogs/8 (Created 18 Nov 2018). Accessed 10 Aug 2021.

Schütze, H. G., \& Slowey, M. (2002). Participation and exclusion: a comparative analysis of non-traditional students and lifelong learners in higher education. Higher Education, 44, 309-327.

Shuck, B., Roberts, T.P., \& Zigarmi, D. (2018). Employee perceptions of the work environment, motivational outlooks, and employee work intentions: an HR practitioner's dream or nightmare? Advances in Developing Human Resources, 20(2), 197-213. https://doi.org/10.1177/1523422318757209.

Smolikevych, N. (2019). The teacher's main competencies in modern higher education. European Humanities Studies: State and Society, 19(I), 30-42.

Statistisches Bundesamt (2018). Bildung und Kultur. Personal an Hochschulen 2017. Fachserie 11, Reihe 4.4. https://www.destatis.de/DE/Themen/Gesellschaft-Umwelt/Bildung-Forschung-Kultur/ Hochschulen/Publikationen/Downloads-Hochschulen/personal-hochschulen-2110440177004.pdf? blob=publicationFile. Accessed 15 Aug 2020.

Tang, M., Wang, D., \& Guerrien, A. (2020). A systematic review and meta-analysis on basic psychological need satisfaction, motivation, and well-being in later life: contributions of self-determination theory. PsyCh Journal, 9(1), 5-33. 
De Vito, K. M. (2009). Implementing adult learning principles to overcome barriers of learning in continuing higher education programs. Online Journal for Workforce Education and Development, 3(4), $1-10$.

Völkening, U., Ostermann, H., Link, L., \& Hübner, H.F.W. (2010). The impact of self-determination on academic motivation of occupational therapists and physiotherapists in continuing higher education in Germany. The Journal of Continuing Higher Education, 58(2), 85-98.

Wilkesmann, U. (2010). Die vier Dilemmata der wissenschaftlichen Weiterbildung (The four dilemmas of continuing higher education). ZSE Zeitschrift für Soziologie der Erziehung und Sozialisation/Journal for Sociology of Education and Socialization, 30(1), 28-42.

Wilkesmann, U. (2013). Effects of transactional and transformational governance on academic teaching-Empirical evidence from two types of higher education institutions. Tertiary Education and Management, 19(4), 281-300.

Wilkesmann, U., \& Lauer, S. (2020). The influence of teaching motivation and new public management on academic teaching. Studies in Higher Education, 45(2), 434-451.

Wilkesmann, U., \& Schmid, C. J. (2012). The impacts of new governance on teaching at German universities. Findings from a national survey. Higher Education, 63(1), 33-52.

Wilkesmann, U., \& Schmid, C. J. (2014). Intrinsic and internalized modes of teaching motivation. Evidence-Based Hrm: A Global Forum for Empirical Scholarship, 2(1), 6-27.

Wilkesmann, U., Vorberg, R., \& Schmid, C. J. (2020a). Motivation von Lehrenden in der wissenschaftlichen Weiterbildung (Motivation of teachers in continuing higher education). In E. Cendon, U. Wilkesmann, A. Maschwitz, S. Nickel, K. Speck \& U. Elsholz (Eds.), Wandel an Hochschulen? Entwicklungen der wissenschaftlichen Weiterbildung im Bund-Länder-Wettbewerb ,Aufstieg durch Bildung: offene Hochschulen' (pp. 185-206). Münster: Waxmann.

Wilkesmann, U., Vorberg, R., Schmitz, E., \& Minnemann, P. (2020b). Wer lehrt in der wissenschaftlichen Weiterbildung? (Who teaches in continuing higher education?). In E. Cendon, U. Wilkesmann, A. Maschwitz, S. Nickel, K. Speck \& U. Elsholz (Eds.), Wandel an Hochschulen? Entwicklungen der wissenschaftlichen Weiterbildung im Bund-Länder-Wettbewerb ,Aufstieg durch Bildung: offene Hochschulen' (pp. 169-186). Münster: Waxmann.

Wong, K.T., Hwang, G. J., Choo Goh, C.P.S., \& Mohd Arrif, S. K. (2020). Effects of blended learning pedagogical practices on students' motivation and autonomy for the teaching of short stories in upper secondary English. Interactive Learning Environments, 28(4), 512-525.

Woods, K., \& Frogge, G. (2017). Preferences and experiences of traditional and nontraditional university students. The Journal of Continuing Higher Education, 65, 94-105.

Publisher's Note Springer Nature remains neutral with regard to jurisdictional claims in published maps and institutional affiliations.

Uwe Wilkesmann holds since 2006 a chair for organization studies and management of continuing education and is director of the Center for Higher Education at TU Dortmund University. In addition, he was adj. professor at Hong Kong Polytechnic University (Research Centre for Knowledge Management and Innovation) from 2008 to 2015 . His main research field in the last 20 years is higher education research and organization studies.

Ronja Vorberg is a research assistant at the chair for organization studies and management of continuing education. Her main areas of interest are continuing higher education and motivation. 